\begin{tabular}{c|c|c}
\hline \hline Vol. 1: 5-6, 2006 & ENDANGERED SPECIES RESEARCH & Printed November 2006 \\
Previously ESR 1: 1-2, 2004 & Endang Species Res & Published online February 3, 2004 \\
\hline
\end{tabular}

\title{
The essence of IR involvement
}

\author{
Otto Kinne* \\ Inter-Research and International Ecology Institute Nordbünte 21 \& 23, 21385 Oldendorf/Luhe, Germany
}

Since 1989 Inter-Research (IR) has sponsored and conducted research on endangered species in the valley of the River Luhe, Germany. Our aims are: (1) to give back to nature a small fraction of the Luhe valley and its biota that had suffered a near-lethal blow from human impact over decades; (2) to re-introduce species which had originally inhabited the valley; (3) to support and to protect other highly endangered life forms.

The dimensions of our efforts are modest. Our 'InterResearch Land' ('Ökologisches Versuchsgebiet') occupies an area of about 5.5 hectares. The staff, who does all the field and laboratory work, consists of 3 individuals working part-time on the project: Otto Kinne, Jens Kunert and Waldemar Zimmermann. O. Kinne is IR director, J. Kunert and W. Zimmermann are IR gardeners who take care of our land and its inhabitants. Both have learned to do many things in addition to gardening. They work successfully and with much enthusiasm. Increasingly, they contribute important ideas of their own, as well as potential solutions to technical and biological problems related to our research efforts.

Our first reports are devoted to amphibians (toads and newts). They address, and are intended to support, scientists as well as lay-people interested in investigating and protecting endangered species. They are presented without much scientific terminology in easy-tounderstand texts and illustrations. The reports can be downloaded free of charge from www.int-res.com/ research/index.html.

We have built a variety of pools, ponds and ditches serving as reproduction areas, as well as summer and winter habitats. And we have constructed and equipped 2 small, simple, but effective field laboratories.

Our efforts have resulted in the successful re-introduction and building up of a small, viable field population of the fire-bellied toad Bombina bombina ('Rotbauchunke'). The total 2001 population was estimated at 80 individuals). We continue to breed the toad and to release between 50 and 300 juveniles per year in Inter-

\footnotetext{
*Email: kinne@int-res.com. Fax: +49 41328883
}

(ㅇ) Inter-Research $2004 \cdot$ www.int-res.com
Research Land, thus supporting the natural reproductive capacity of the field population.

Similarly, we have re-introduced and built up a population of the crested or warty newt Triturus cristatus ('Kammmolch'). The 2001 field population had already attained a quasi-natural age structure. It consisted of an estimated 160 individuals. We continue breeding and raising, and make yearly additions to the field population by setting out larvae and/or juveniles.

The population of the less endangered common or smooth newt Triturus vulgaris ('Teichmolch') is, since 1997, fully 'self-sustaining'. In 1999 the local population was estimated to number about 1300 individuals of different ages.

Specimens of all 3 species continuously emigrate into neighbouring areas outside our IR Land and thus increase their total distribution areas.

IR Land supports also other amphibians, as well as reptiles, rare butterflies and birds, and several endangered plants, including Stratiotes aloides (water soldier, 'Krebsschere') and Dactylorhiza magalis (orchid, 'Knabenkraut').

Unfortunately, our efforts begin to suffer increasingly from 'uninvited' organisms who take advantage of the new chances and benefits offered to them by the development of IR Land. We had to learn an essential, actually obvious, lesson: Over longer periods of time you cannot support selected species without attracting competitors and predators - and without risking increased disease impacts. Our IR Land should be considerably enlarged in order to smoothen such shortcycled ecological disturbances, notably those due to changes in prey-predator relations and in disease dynamics.

Especially in spring, the water bodies we created in IR Land attract wild ducks. They feed on amphibian spawn and introduce, via egg transport, predatory fish, notably river perch Perca fluviatitis ('Flussbarsch'). In March 2003, for example, we found hundreds of perch yearlings in one of our relatively small pools; they had exterminated all toads and newts. Other dangerous

\footnotetext{
${ }^{\star}$ First published April 14, 2003, under INTER-RESEARCH REPORTS as Rept 1
} 
predators are cats that enjoy our land as hunting- and play-ground and predatory birds, especially the common heron Ardea cinerea ('Fischreiher'), who voraciously consumes amphibians, small reptiles, fish and other animals. What makes things really complicated is the fact that these birds are also protected (by law) due to well-meant initiatives of ecologists, ornithologists and environmental protectionists. Unfortunately, these people failed to take into account the need of providing sufficient living space and food resources for their proteges. Hence the poor hungry birds now attempt to survive on our neighbour's goldfish and our endangered animals.

Of the predators less dangerous to our toads and newts I mention here the grass snake Natrix natrix ('Ringelnatter') whose populations increased more or less parallel to our amphibian populations, polecats Mustela putorius ('Iltis'), stone martens Martes foina ('Steinmarder') and hedgehogs Erinaceus europaeus.

A new, serious threat to our efforts are micro-organisms such as viruses, bacteria and fungi. They are known to increasingly infest and often kill large numbers of amphibians word-wide. I am grateful to my colleague and friend Professor Tom Berman (Kinneret Limnological Laboratory, Tiberias, Israel) for repeatedly calling my attention to these growing dangers. He kindly also made pertinent literature available to us. So far, we have not noticed heavy micro-organism infections in our populations.

In addition to numerous virus diseases in waterliving plants and animals (including amphibians), many of which have received attention in 'Diseases of Aquatic Organisms', fungi can critically damage frogs and other amphibians. An example published by science writer Kendall Powell (2003) is Batrachochytrium dendrobatidis, a chytrid fungus that can kill large numbers of frogs. The fungus affects the breathing activities of frogs and their water absorption capacities, and possibly releases a toxic substance. More than 30 amphibian species, including toads and salamanders, suffer from the fungus disease. As is often the case with microbial infections some infected individuals may survive and act as carriers, thus assisting the disease agent to spread. In Australia the fungus seems to have decisively contributed to the extinction of 6 frog species. It has also been reported from New Zealand, the United States, South America and Europe. Australian scientists Alex Hyatt and his team at CSIRO in Geelong developed a dip that facilitates the detection of the fungus and its identification without harming the amphibian's skin. After washing infested frog skin in a mix of water and salts for 15 min the resulting solution can be tested for the fungus using either antibodies to it or a genetic test that amplifies DNA characteristics.

Chemicals are well known to cause many detrimental effects, ranging from metabolic and morphologic disorders, through reproductive anomalies, to death. Hayes et al. (2002) presented evidence that the widely used herbicide atrazin can turn male frogs Rana pipiens into hermaphrodites by inducing the development of female gonads.

In spite of several setbacks to our efforts we are determined to continue our endangered species research and our attempts to assist in protecting endangered life forms.

In April 2003 we have started to publish our first reports.

Acknowledgements. I am grateful to Samtgemeindedirektor Helmut Völker (Amelinghausen), and Bürgermeister Günter Rund (Oldendorf). Both have supported our efforts by assisting in solving administrative problems. I also acknowledge the artwork (Fig. 1 in Endangered Species Research 2) by John Austin of Inter-Research.

\section{LITERATURE CITED}

Hayes T, Haston $\mathrm{K}$, Tsui M, Hoang A, Haeffele C, Vonk A (2002) Feminization of male frogs in the wild. Nature 419: 895-896

Powell K (2003) Frog dip detects killer fungus. Nature science update, 15 Feb 